\title{
A fine history of Archibald Malloch
}

Previously published at www.cmaj.ca

"Noted Surgeon, Fine Citizen" The Life of Archibald E. Malloch, MD, 1844-1919

Charles G. Roland MD DSC

Osler Library Studies in the History of Medicine and the American Osler Society; 2008.

$\mathrm{T}$ his biography of Archibald Malloch is a remarkable achievement by one of Canada's most respected medical historians. Drawing from family letters, a handful of case records and published articles, and a deep knowledge of the 19th-century medical profession and medicine, Charles Roland has constructed an elegant, engaging biography of a Canadian medical pioneer.

Born in Brookville, Upper Canada, in 1844 , the son of a prominent judge, Archibald Malloch attended Queen's College in Kingston, Ontario, receiving his arts degree in 1862. His studies there in medicine ended after the first year, perhaps because of his father's activities; Judge Malloch was a trustee of Queen's who opposed the medical school and

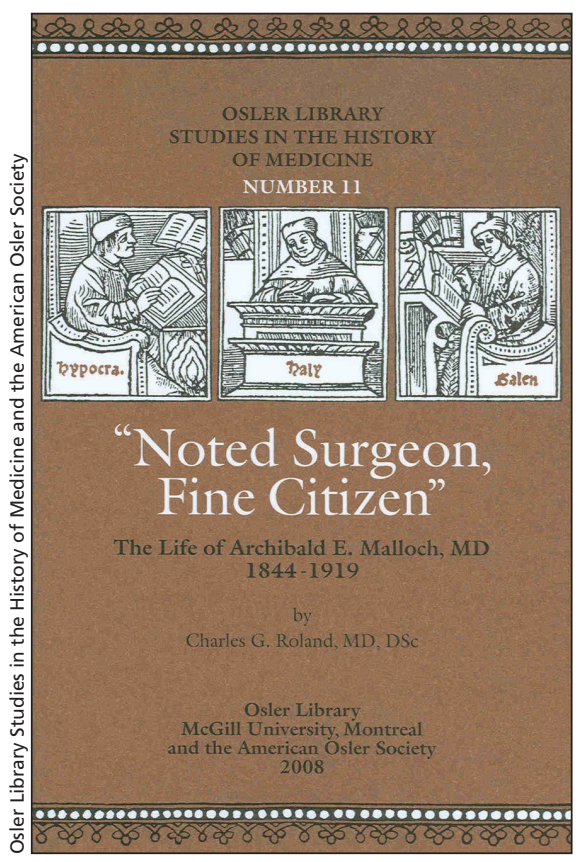

Unsurprisingly for someone who was one of Lister's earliest proteges, Malloch developed a successful surgical practice in addition to a busy general practice. Roland, returning to the theme of an earlier paper, ${ }^{1}$ provides a good discussion of the controversies surrounding the intro-

\section{Roland has made remarkable use of the limited sources of information.}

later played a prominent role in driving its professors out of the college.

Undeterred, Archibald went on to complete his studies in Glasgow, Scotland, in 1867. As a testament to his abilities, he then became the house surgeon to Joseph Lister who had just introduced his antiseptic system and germ theory. Malloch returned to Canada and, apart from a brief and unhappy period at the University of Toronto, practised for the remainder of his life in Hamilton, Ontario, where he was a prominent local physician for 50 years. duction of Listerism in Canada and, without belabouring the point, gives ample reason to believe that Malloch was the first to use the antiseptic system in Canada.

Remarkably, considering the differences in their careers, Malloch maintained a close friendship with William Osler throughout his adult life. They reportedly met over a case of trichinosis: Malloch the young treating physician, Osler the inquisitive firstyear medical student who had travelled to Hamilton to see the microscopic slides. This was Osler at the start of his career demonstrating the habits of mind that would lead many to ultimately describe him as the pre-eminent physician of the 20th century. The bond between the two families deepened during World War I, when Malloch's son, T. Archibald Malloch, a medical officer in the Royal Canadian Army Medical Corps, paid frequent visits to the Osler home in Oxford, England.

The younger Malloch eventually attended Osler as one of his physicians during Osler's final illness in 1919. For Grace Osler, following the death of her husband and the earlier loss of her son Revere on the Western Front, "T Archie" became both a source of support and an editor of the Bibliotheca Osleriana.

Unlike the well-documented life of his friend Osler, Malloch left far fewer traces, greatly complicating the task of any biographer. The remarkable use that the author has made of the available sources, interwoven with commentary on life and medicine in Canada in is a testament to his skill as a historian and a reminder of how much we have lost with his recent death. For these reasons, the book should have a broad appeal. Physicians, students of history, Oslerians, and anyone interested in 19th-century Canadian life will find much of interest and much to enjoy in this well-crafted book.

\section{Peter J. Kernahan MD MS}

Program in the History of Medicine

Department of Surgery

University of Minnesota

Twin Cities, USA

\section{REFERENCE}

1. Roland CG. The early years of antiseptic surgery in Canada. J Hist Med Allied Sci 1967; 22: 380-91. 